\title{
Urease Activity in the Rumen of Sheep and the Isolation of Ureolytic Bacteria
}

\author{
By A. R. COOK \\ The Rowett Research Institute, Bucksburn, Aberdeen AB2 $9 S B$
}

(Received 24 February 1975; revised 12 June 1975)

\begin{abstract}
SUMMAR Y
Urease activity in the sheep rumen varied with the diet of the sheep, but appeared to be largely or entirely present in the small bacterial fraction. Screening of over 1000 strains of rumen bacteria isolated on different media showed that urease activity was apparently confined to species of Staphylococcus, Lactobacillus casei var. casei and Klebsiella aerogenes. Consideration of the numbers in which these occurred and their activities suggested that the bacteria could not be responsible for the total rumen urease activity. By enrichment culture a ureolytic strain of Streptococcus faecium was isolated. This had a higher urease activity than the other bacteria and occurred in higher numbers in the rumen. It could live with other bacteria in the rumen of a gnotobiotic lamb in numbers, and with a urease activity, comparable with those in the normal sheep rumen. The other properties of the bacterium also suggested that it would grow and produce urease in the rumen, but was unlikely to retain its urease activity after isolation. It was concluded that this bacterium was the main source of rumen urease in roughage-fed, and probably other, sheep.
\end{abstract}

\section{INTRODUCTION}

In the ruminant herbivore, primary digestion of the food is carried out by the microorganisms of the rumen. Here plant carbohydrates are hydrolysed and fermented to lower volatile fatty acids which are used by the ruminant for the production of glucose and fats. The protein and non-protein nitrogenous constituents of the diet are converted into microbial cells which are digested further down the gastro-intestinal tract as the ruminant's source of protein. Although some bacteria utilize amino acids or peptides as nitrogen sources, for many of the bacteria ammonia is the only, or (where some amino acids are needed) the major, nitrogen source. The rumen protozoa depend upon bacteria, or particulate protein, for nitrogen.

The major source of this ammonia is usually the feed proteins, but urea is present in ruminant saliva and also diffuses into the rumen through the rumen wall. Since urea is rapidly hydrolysed in the rumen (Pearson \& Smith, 1943), it is an important source of ammonia especially in the recycling of nitrogen to the rumen.

Although urea is thus physiologically important to the ruminant's nitrogen metabolism and is economically important in ruminant feeding, the microbiological aspects of urea metabolism are probably the least understood of any rumen microbial function. Particular species of bacteria concerned in the principal rumen functions, such as cellulolysis and proteolysis, are found in ruminants in all parts of the world, in numbers constituting an appreciable proportion of the total rumen bacteria and with properties which fit them for life and activity in the rumen environment. No similar situation exists with regard to ureolytic activity; although a number of different species of ureolytic bacteria have been isolated, 
Table I. Effect of diet on sheep rumen urease activity

See Methods for details of assay.

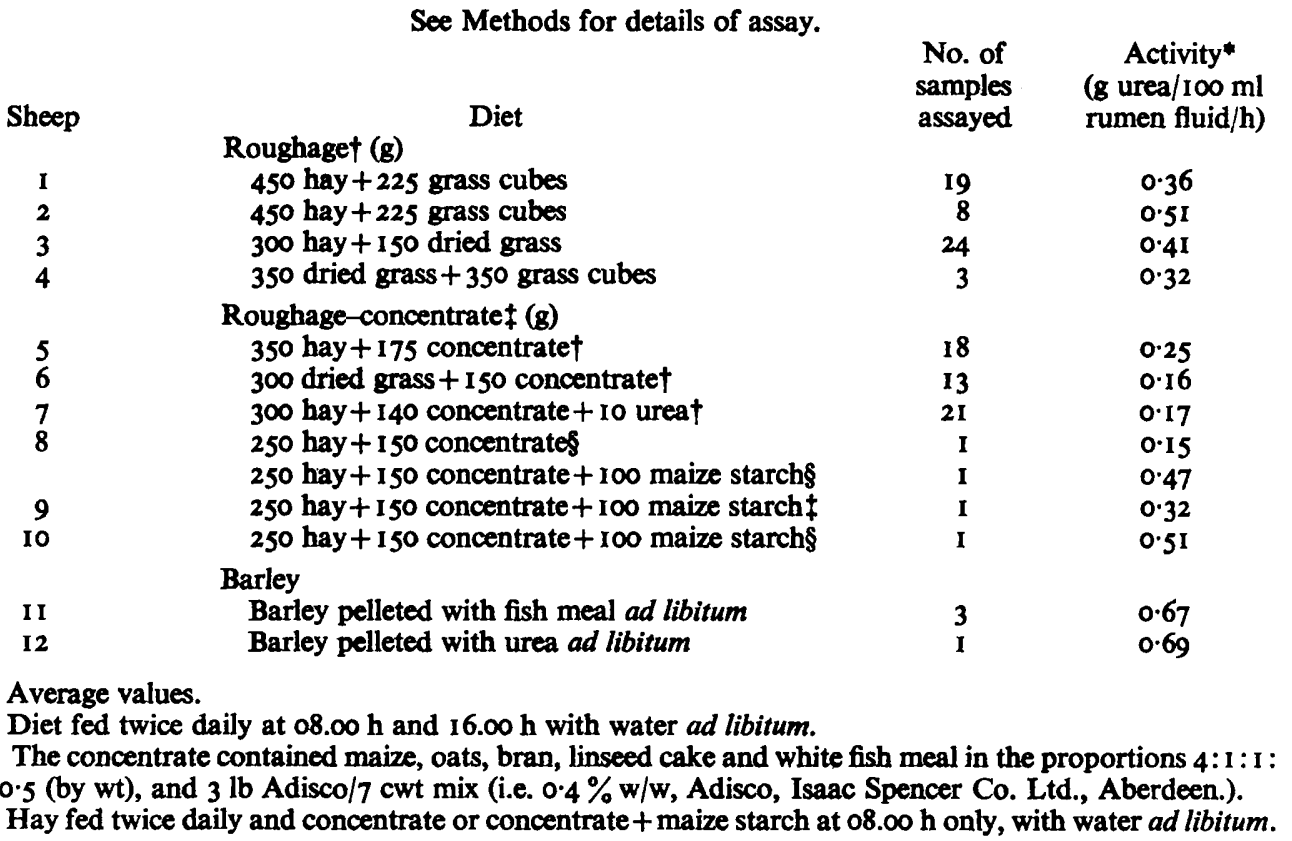

there is no proof that such bacteria are widespread in rumen contents or that any of them are a major source of rumen urease activity. Indeed, it has been suggested that ruminal urea may not be hydrolysed by the enzyme urease (Farlin, Brown \& Garrigus, 1968), or that the total activity is produced by summation of the relatively small activities of a large number of species of rumen bacteria (Muhrer \& Carroll, 1964). The known species of ureolytic rumen bacteria are considered later, in the Discussion.

The initial stages of the present work were designed to confirm that ruminal ureolytic activity was due to a bacterial urease, and to obtain measurements of ruminal activity. The experiments with young animals would show whether significant activity was associated with the rather simpler flora of the pre-weaning rumen or whether it was associated with the more complex, largely anaerobic flora of the true ruminant. There are several possible methods of isolating bacteria when investigating a complex microbial habitat, and they were used in this work. The nutritional studies on the main bacterial isolate were made partly to complete the description of the bacterium, but more especially to see if the bacterium was fitted for growth and urease production in the rumen.

Preliminary notes on some aspects of this investigation have been published (Cook, 1972).

\section{METHODS}

Animals. Sheep I was a rumen-cannulated Border Leicester $\times$ Cheviot, sheep 3 a cannulated Cheviot, and sheep 4 a cannulated Greyface. All had water ad libitum. Other animals were from the Institute flock (Table $I$ ).

Lambs A and B (Suffolk Finn $\times$ Dorset Poll) were put into separate isolation cages 2 days after birth and fed on milk three times daily. From 28 days after birth dried grass was 
offered ad libitum. At 83 days the lambs were weaned on to a diet with concentrates given twice daily and dried grass and water available ad libitum. Lamb C (Suffolk $\times$ Cheviot) was given milk for 45 days from birth, when grass was offered ad libitum. Rumen samples were obtained by stomach tube.

Gnotobiotic lamb D (Finnish Landrace $\times$ Polled Dorset Horn) had been inoculated at intervals, until it was $\mathbf{4 3}$ days old, with cultures of seven rumen bacteria which had formed a stable population (Veillonella alcalescens, Lactobacillus sp. Megasphaera (Peptostreptococcus) elsdenii, Selenomonas ruminantium, Bacteroides ruminicola, Butyrivibrio fibrisolvens, Ruminococcus albus). When 86 days old it was inoculated with Methanobacterium ruminanttium and the next day with a culture of the ureolytic Streptococcus faecium. The feeding schedule is given in Table 2.

The compositions of the lamb feeds were as described by Mann \& Stewart (1974), except that ferrous sulphate $(108 \mathrm{~g} / \mathrm{kg})$ was incorporated in the starter pellets. Rumen samples were taken by stomach tube.

Materials. Defibrinated horse blood was from Oxoid, and Bactocasitone, Bactotryptone, Bactopeptone, Bacto yeast extract and agar were from Difco. Trypticase was from BBL, and DL-L-methylbutyric acid from Kodak Ltd, Kirkby, Liverpool. Acetohydroxamic acid was prepared as described by Fishbein, Daly \& Streeter (1969). All other chemicals were from BDH. Carbon dioxide was passed over heated copper to remove oxygen. Glassdistilled water was used throughout.

Media. All media were prepared and inoculated using anaerobic methods based on those of Hungate (1950), except where stated. All cultures were incubated at $38{ }^{\circ} \mathrm{C}$.

(i) Isolation media. Media for direct isolation were based on those used to grow a wide range of rumen bacteria. The rumen fluid used was the clear supernatant obtained by centrifugation of whole rumen fluid which had been filtered through four layers of surgical gauze. The following media were used: medium 98-5 (Bryant \& Robinson, 1961), with $\mathrm{Na}_{2} \mathrm{CO}_{3}$ increased to $0.4 \%$ and $100 \% \mathrm{CO}_{2}$ as the gas phase; medium 2 (Hobson, 1969); medium $2 \mathrm{a}$, as medium 2 but without agar and with the mixed carbohydrates replaced with mannitol $(0.2 \%)$; medium RO (Rogosa, Mitchell \& Wiseman, 1951), with added $0.05 \%$ cysteine $\mathrm{HCl} . \mathrm{H}_{2} \mathrm{O}$ and $100 \% \mathrm{CO}_{2}$ as the gas phase; medium RORF, as medium RO but with the further addition of $20 \%$ (v/v) rumen fluid; medium Io (Caldwell \& Bryant, 1966); medium CM (Wilson \& Briggs, 1955). In all these media ammonium sulphate was replaced by urea $(0.2 \%)$ added as a Seitz-filtered solution.

Medium GR contained $15 \mathrm{ml}$ mineral solution I, $15 \mathrm{ml}$ mineral solution 2 (Hobson, 1969), $0.1 \mathrm{ml}$ resazurin $(0.1 \%), 1 \mathrm{ml}$ rumen fluid, $0.5 \mathrm{~g}$ soluble starch, $4 \mu \mathrm{g}$ biotin, I ml sodium lactate $(70 \%, \mathrm{w} / \mathrm{v}), 0.3 \mathrm{~g}$ yeast extract, $\mathrm{I} \mathrm{ml}$ trace element solution (Kogut \& Podoski, 1953, without ammonium molybdate), $2 \mathrm{~g}$ agar, $54 \mathrm{ml}$ water. This basal medium was sterilized at $12 \mathrm{I}{ }^{\circ} \mathrm{C}$ for $\mathrm{I} 5 \mathrm{~min}$, after which were added $\mathrm{I} \mathrm{ml}$ haemin $(0.0 \mathrm{I} \%), 0.3 \mathrm{I} \mathrm{ml}$ volatile fatty acid mixture (Caldwell \& Bryant, 1966), and $10 \mathrm{ml}$ of a Seitz-filtered solution containing $0.4 \mathrm{~g} \mathrm{NaHCO}, 0.05 \mathrm{~g}$ cysteine $\mathrm{HCl} . \mathrm{H}_{2} \mathrm{O}, 0.2 \mathrm{~g}$ maltose, $0.2 \mathrm{~g}$ cellobiose, $0.2 \mathrm{~g}$ glucose and $0.2 \mathrm{~g}$ urea. Medium $\mathrm{U}$ (Elias $\mathrm{I97} \mathrm{I}$ ), was also used.

Dilutions of rumen contents were made in a fluid of the composition of the appropriate isolation medium without carbohydrates and agar.

(ii) Enrichment media. Medium A was a modification of the lactate medium of Elsden $e t$ al. (I956) and contained $0.4 \mathrm{~g}$ yeast extract, $2 \mathrm{ml}$ sodium lactate $(70 \%, \mathrm{w} / \mathrm{v}), 0.075 \mathrm{~g}$ sodium thioglycollate, $0.05 \mathrm{~g} \mathrm{KH}_{2} \mathrm{PO}_{4}, 0.03 \mathrm{~g} \mathrm{MgCl}_{2} .6 \mathrm{H}_{2} \mathrm{O}, 0 . \mathrm{I} \mathrm{mg}$ resazurin and $97 \mathrm{ml}$ water. The $\mathrm{pH}$ was adjusted to $7 \cdot 4$ and, after autoclaving ( $15 \mathrm{~min}, 121{ }^{\circ} \mathrm{C}$ ), a Seitz-filtered urea solution was added to give a final urea concentration of $0.2 \%$. 
Medium B was modified from that developed by Tiwari, Bryant \& Wolfe (1969) to isolate Selenomonas ruminantium. It contained $0.1 \mathrm{~g}$ yeast extract, $0.2 \mathrm{~g}$ mannitol, $0.5 \mathrm{~g}$ trypticase, $0 . \mathrm{I} \mathrm{g}$ anhydrous sodium acetate, $0.05 \mathrm{~g} \mathrm{FeSO}{ }_{4} .7 \mathrm{H}_{2} \mathrm{O}, 0.1 \mathrm{mg}$ resazurin, $4 \mathrm{ml}$ mineral solution (g/100 ml: $\left.\mathrm{I} \cdot 2 \mathrm{KH}_{2} \mathrm{PO}_{4}, \mathrm{I} \cdot 2 \mathrm{NaCl}, 0.245 \mathrm{MgSO}_{4} \cdot 7 \mathrm{H}_{2} \mathrm{O}, 0.159 \mathrm{CaCl}_{2} .2 \mathrm{H}_{2} \mathrm{O}\right)$ and water to $95 \mathrm{ml}$. The $\mathrm{pH}$ was adjusted to 7.4, and, after autoclaving, $5 \mathrm{ml}$ of a Seitz-filtered solution containing $0.2 \mathrm{~g}$ urea, $0.08 \mathrm{~g}$ cysteine $\mathrm{HCl} . \mathrm{H}_{2} \mathrm{O}$ and $0.03 \mathrm{ml} n$-valeric acid $(\mathrm{pH} \mathrm{7.4)}$ was added.

Medium $\mathrm{C}$ was a modification of medium $\mathrm{B}$ and contained $0 . \mathrm{I} \mathrm{g}$ yeast extract, $0.2 \mathrm{~g}$ mannitol, $0.5 \mathrm{~g}$ trypticase, $0.1 \mathrm{~g}$ anhydrous sodium acetate, $0.05 \mathrm{~g} \mathrm{KH}_{2} \mathrm{PO}_{4}, 0.075 \mathrm{~g}$ sodium thioglycollate, $0 . \mathrm{I} \mathrm{mg}$ resazurin and $99 \mathrm{ml}$ water. The $\mathrm{pH}$ was adjusted to $7 \cdot 4$, the medium autoclaved and $\mathrm{I} \mathrm{ml}$ of a Seitz-filtered urea solution added (final concentration $0.2 \%$ ). All three media had a $\mathrm{pH}$ of $6 \cdot 2$ under $\mathrm{CO}_{2}$.

(iii) Media for nutritional study. Medium $\mathrm{D}$ was medium $\mathrm{C}$ without trypticase. Medium $\mathrm{E}$ was medium $\mathrm{D}$ without $\mathrm{KH}_{2} \mathrm{PO}_{4}$, and with $0.15 \%$ each of $\mathrm{Na}_{2} \mathrm{HPO}_{4}$ and $\mathrm{KH}_{2} \mathrm{PO}_{4}$ added.

For the nutritional study, unless otherwise stated, all media constituents except urea were sterilized by autoclaving ( $15 \mathrm{~min}, 12 \mathrm{I}{ }^{\circ} \mathrm{C}$ ) and dispensed in $10 \mathrm{ml}$ amounts. Cultures were incubated anaerobically under oxygen-free $\mathrm{CO}_{2}$ in rubber-stoppered glassware; aerobic culture was in cotton wool-plugged conical flasks, at a flask medium - volume ratio of 10: I, shaken on a Gallenkamp (London) orbital shaker at $200 \mathrm{rev} . / \mathrm{min}$.

Direct isolation of bacteria. A sample of rumen fluid was diluted under oxygen-free $\mathrm{CO}_{2}$, $0.5 \mathrm{ml}$ of the desired dilution was added to the medium and roll-tubes prepared. After incubation for 3 to 7 days, colony counts were carried out and randomly isolated colonies examined microscopically and transferred to slopes of the same composition as the isolation medium. With the later isolations from $U$ and GR media, the urease activity of growth on the slopes was tested by method $(b)$ below. With other media (except 2a) colonies from the slopes were used to inoculate liquid media and the urease activities of these subcultures were determined by method $(a)$. Colonies isolated on medium 98-5 were transferred to the similar liquid, 'pH glucose' medium of Bryant \& Burkey (1953) which was incubated anaerobically for 7 days. With isolation media 2, IO, CM and RO, the liquid medium was medium 2 without agar and cultures were grown for $20 \mathrm{~h}$. The time of growth in the various media was either the standard time used in previous experiments on isolation of rumen bacteria or sufficient for good exponential growth. With medium $2 \mathrm{a}$, tests were made particularly for facultative anaerobes. After $20 \mathrm{~h}$ initial incubation samples from the cultures were streaked on to blood-agar plates which were incubated aerobically for $48 \mathrm{~h}$. Colonies were then transferred to nutrient-agar slopes and after $20 \mathrm{~h}$ aerobic incubation the growth was tested for urease by method $(b)$.

Bacterial growth was determined turbidimetrically by determining the $E_{650}$ in an EEL Spectra with the uninoculated medium as reference. Calibration curves were prepared, since at high culture turbidities the relationship of dry weight to extinction was not linear. For the Streptococcus faecium, $E_{650}$ was 53 , total nitrogen $0.07 \mathrm{mg} / \mathrm{ml}$, dry weight $0.74 \mathrm{mg} / \mathrm{ml}$, colony-forming units (c.f.u.) $1.5 \times 10^{\circ} / \mathrm{ml}$. Total nitrogen and dry weight values were determined on bacteria centrifuged from cultures, and c.f.u. values for the $S$. faecium were determined from dilution cultures on aerobic, brain-heart infusion plates.

Urease activity. After comparative tests using maleate (Slyter et al. 1968) and tris (Fasman \& Niemann, I95I) buffer systems, the buffer used by Gorin \& Chin (1966), containing $0.001 \mathrm{M}$-EDTA and $0.02 \mathrm{M}$-sodium phosphate $\mathrm{pH} 7.0$, was found to allow optimal urease activity and stabilization of $\mathrm{pH}$. Inhibition, reported to be due to high potassium ion concentrations (Fasman \& Niemann, 195I) was not found. 
Method $(a)$. Using a wide-bore-tip pipette, a sample $(0.5 \mathrm{ml})$ of rumen fluid was added to $9.5 \mathrm{ml}$ of $0.02 \mathrm{M}$-phosphate buffer $\mathrm{pH} 7.0$ containing 0.001 M-EDTA and suspended by vigorous shaking. A sample $(0.2 \mathrm{ml})$ of this suspension was then assayed. For bacterial cultures, I ml was centrifuged, the bacteria resuspended in $2 \mathrm{ml}$ of the buffer and $0.2 \mathrm{ml}$ taken for assay. The sample was incubated with $0.17 \mathrm{mmol}$ urea, in a final volume of $\mathrm{I} \mathrm{ml}$ of buffer, for $5 \mathrm{~min}$ at $38^{\circ} \mathrm{C}$. The reaction was terminated by the addition of phenate hypochlorite reagents (Weatherburn, 1967). The phenate hypochlorite colour was developed for $15 \mathrm{~min}$ at $38^{\circ} \mathrm{C}$, and, after centrifugation of the mixture, read at $570 \mathrm{~nm}$ using the EEL Spectra (I $\mu \mathrm{g} \mathrm{NH} \mathrm{NH}_{3} \equiv 22 E_{570}$ ); the sensitivity could be increased by reading at $640 \mathrm{~nm}$, the maximum extinction for the colour.

Method $(b)$. It was found later that suspending a loopful of growth from a slope in $0.2 \mathrm{ml}$ of the buffer and assaying as above, but with a $20 \mathrm{~h}$ incubation, was sufficient as a screening test.

For some rumen fluid samples with low activities the initial sample was diluted less and the incubation time was extended.

Urease activity units are expressed per millilitre of rumen fluid or culture in accordance with the International Union of Biochemists; one unit (i.u.) is the amount of urease which catalyses the hydrolysis of $0.5 \mu \mathrm{mol}$ of urea and liberates I $\mu \mathrm{mol}$ of ammonia in I min at $38^{\circ} \mathrm{C}$.

For comparison, in some experiments a 'specific activity' was defined as the activity/ml (above) divided by the $E_{650}$ of the culture. The different media or growth conditions used in these experiments did not materially affect the relationship between $E_{650}$ and other growth measurements.

In ruminant nutrition studies urease activity is usually quoted as $\mathrm{g}$ urea hydrolysed/100 $\mathrm{ml}$ rumen fluid/h at $38^{\circ} \mathrm{C}$. The conversion is $\mathrm{I}$ i.u. $/ \mathrm{ml} \equiv 0.18 \mathrm{~g}$ urea hydrolysed/100 $\mathrm{ml}$ rumen fluid/h.

Effect of acetohydroxamic acid. Surgical gauze-strained rumen fluid of a culture (I ml) was preincubated with $0.1 \mathrm{ml}$ acetohydroxamic acid solution $\left(\mathrm{I} \times 10^{-7}\right.$ to $\left.\mathrm{I} \times 10^{-1} \mathrm{M}\right)$ in phosphate buffer (as above) for $30 \mathrm{~min}$ at $38^{\circ} \mathrm{C}$, after which $0.17 \mathrm{mmol}$ urea $(0.1 \mathrm{ml}$ of a $10 \%, w / v$, urea solution), in phosphate buffer was added. After incubation for $20 \mathrm{~min}$ at $38{ }^{\circ} \mathrm{C}, \mathrm{I} \cdot \mathrm{I} \mathrm{ml}$ trichloracetic acid $(10 \%, \mathrm{w} / \mathrm{v})$ was added to stop the reaction. The amount of ammonia in $10 \mu \mathrm{l}$ of the acid-treated reaction mixture added to $\mathrm{I} \mathrm{ml}$ water was determined with phenate hypochlorite as above. To determine basal ammonia formation in the reaction mixture, the $0 \cdot 1 \mathrm{ml}$ urea was replaced by $0.1 \mathrm{ml}$ buffer. The uninhibited urease activity of the rumen fluid was determined after incubating $\mathrm{I} \mathrm{ml}$ of rumen fluid and $0.1 \mathrm{ml}$ water. Reagent, urea and acetohydroxamic acid (AHA) blank determinations were made.

Location of ruminal urease. Rumen fluid was filtered through four layers of surgical gauze and $10 \mathrm{ml}$ of the filtrate, 'strained rumen fluid' (SRF), were centrifuged at $200 \mathrm{~g}$ for $3 \mathrm{~min}$ to give a sediment, CRF-I. This was resuspended in $10 \mathrm{ml}$ assay buffer (above) and centrifuged at $200 \mathrm{~g}$ for $3 \mathrm{~min}$ to give CRF-2. The procedure was repeated to give CRF-3. The supernatant from CRF-I was centrifuged at $3000 \mathrm{~g}$ for $\mathrm{I} 5 \mathrm{~min}$ (CRB) and the resulting sediment resuspended in $25 \mathrm{ml}$ cold buffer and sonicated at full power for $15 \mathrm{~min}$ at $4{ }^{\circ} \mathrm{C}$ with a Type I 130 A Soniprobe (Dawe Instruments Ltd, London). The sonicate was centrifuged at $25000 \mathrm{~g}$ for $15 \mathrm{~min}$, and after removal of the supernatant the sediment was resuspended in $10 \mathrm{ml}$ buffer. 


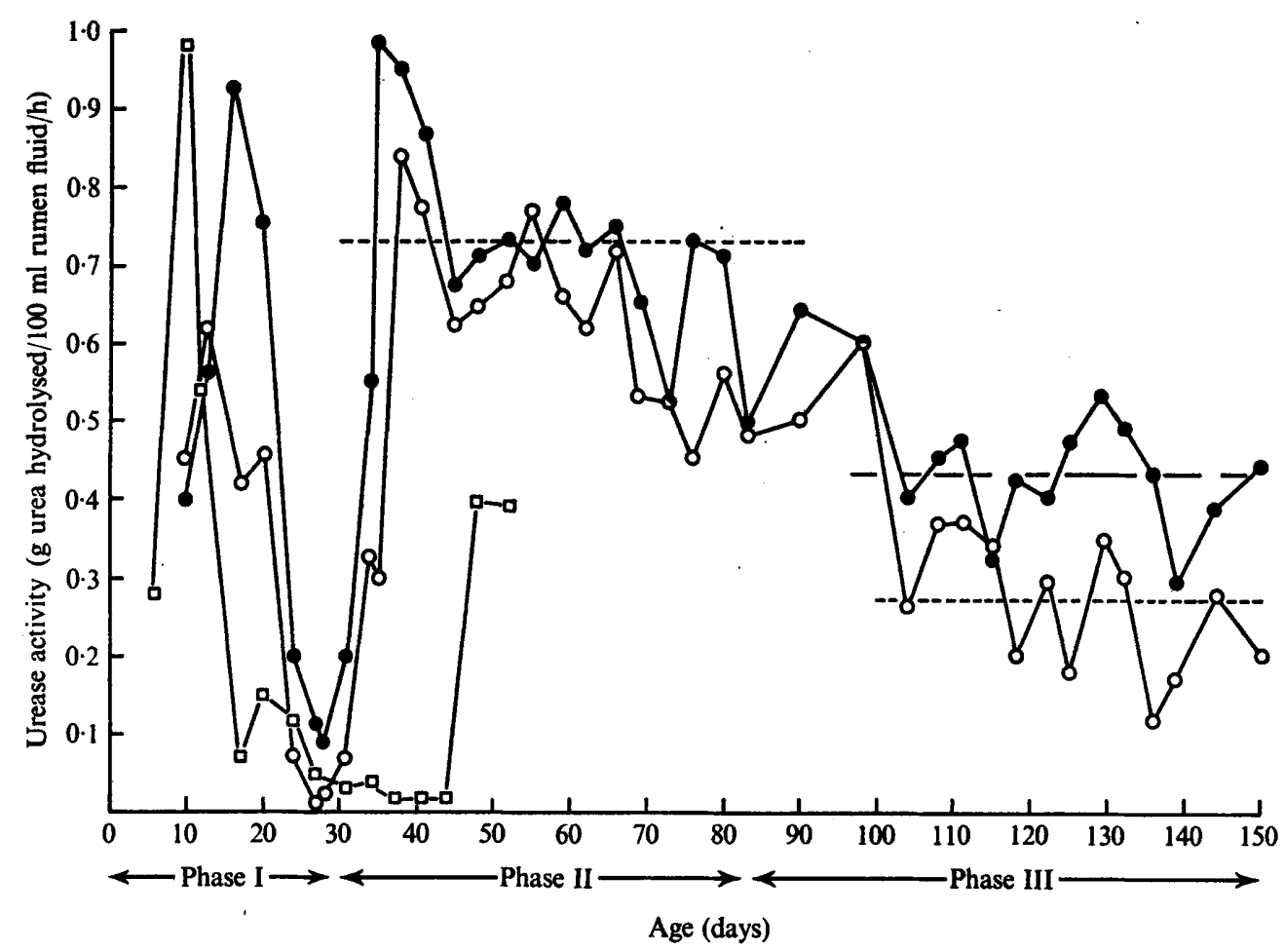

Fig. I. Variation of urease activity with age in growing lambs. Lamb A (O), lamb B (O) and lamb $C(\square)$ were put in isolation cages on day 2 and fed as described in Methods. Broken lines indicate the mean activity.

\section{RESULTS}

Ureolytic activity in the rumen

Ureolytic activity in young animals. The ruminal ureolytic activity (g urea hydrolysed/ I00 $\mathrm{ml}$ rumen fluid/h) was determined over the first weeks of life of three lambs. During the 150 day period the adult rumen flora of lambs A and B would develop as the diet changed (Fig. 1). The initially high urease levels between days 6 and 20 were followed by a period when the activity decreased to very low values. The later increase in activity obviously followed the addition of dried grass to the feeds on days 28 or 45 , and the activities in lambs $A$ and $B$ were comparable with those of the adult sheep on roughage diets (Table 2). Weaning on to concentrates with dried grass reduced the activities further, to average levels comparable with those of the adult sheep on concentrate diets (Table 2). All three lambs were ciliate-free throughout the experiment.

Effect of diet on ureolytic activity in adult sheep. The ruminal ureolytic activity in the adult sheep used in later experiments and in a number of the Institute sheep on different diets was determined (Table 2). The variation about the average values shown in the Table, when multiple samples were assayed over a period, was from 0.03 to 0.07 units. The addition of concentrates to a roughage diet generally depressed ureolytic activity, but the addition of easily fermented carbohydrate increased the activity to about the level in the roughage-only sheep. The sheep fed on the easily fermented barley had the highest activities. The addition of urea to the roughage-concentrate or barley feeds did not increase ureolytic activity. The 
Table 2. Feeding and sampling schedule of gnotobiotic lamb $D$

The starter pellets contained mainly grass and barley, with white fish meal minerals and vitamins.

\begin{tabular}{cl} 
Age (days) & \multicolumn{1}{c}{ Diet and sampling } \\
0 & $\begin{array}{c}\text { Diluted evaporated milk (Carnation), starter pellets } \\
\text { offered }\end{array}$ \\
28 & Starter pellets, water (no milk) \\
46 & Grass pellets \\
85 & Urease assay \\
87 & S. faecium inoculation \\
109 & Urease assay and viable count \\
135 & Starter pellets \\
155 & Urease assay and viable count
\end{tabular}

Table 3. Location of urease in fractions of rumen fluid

See Methods for details of assay.

\begin{tabular}{|c|c|}
\hline Fraction & $\begin{array}{l}\text { Urease activity } \\
\text { (i.u. } / \mathrm{ml})\end{array}$ \\
\hline Rumen fluid & $2 \cdot 25$ \\
\hline Strained rumen fluid (SRF) & $2 \cdot 25$ \\
\hline Centrifuged rumen fluid & \\
\hline $\begin{array}{l}\text { CRF-I } \\
\text { Supernatant } \\
\text { Sediment }\end{array}$ & $\begin{array}{l}1.52 \\
0.73\end{array}$ \\
\hline $\begin{array}{l}\text { CRF-2 } \\
\text { Supernatant } \\
\text { Sediment }\end{array}$ & $\begin{array}{l}0.40 \\
0.33\end{array}$ \\
\hline $\begin{array}{l}\text { CRF-3 } \\
\text { Supernatant } \\
\text { Sediment }\end{array}$ & $\begin{array}{l}0.24 \\
0.09\end{array}$ \\
\hline $\begin{array}{l}\text { Centrifuged supernatant from CRF-1 (CRB) } \\
\text { Supernatant } \\
\text { Sediment }\end{array}$ & $\begin{array}{l}0.04 \\
1.48\end{array}$ \\
\hline $\begin{array}{l}\text { Centrifuged, sonicated rumen bacteria (CS) } \\
\text { Supernatant } \\
\text { Sediment }\end{array}$ & $\begin{array}{l}0.96 \\
0.52\end{array}$ \\
\hline
\end{tabular}

SRF, filtrate after straining rumen fluid through 4 layers of surgical gauze; CRF-1, centrifugation of SRF at $200 \mathrm{~g}$ for $3 \mathrm{~min}$; CRF-2, centrifugation of resuspended sediment from CRF-I at $200 \mathrm{~g}$ for $3 \mathrm{~min}$; CRF-3, centrifugation of resuspended sediment from CRF-2 at $200 \mathrm{~g}$ for $3 \mathrm{~min}$; CRB, centrifugation of supernatant from CRF- 1 at $3000 \mathrm{~g}$ for $15 \mathrm{~min}$; CS, centrifugation at $25000 \mathrm{~g}$ for $15 \mathrm{~min}$ of resuspended sediment from $\mathrm{CRB}$ sonicated for $15 \mathrm{~min}$ at $4^{\circ} \mathrm{C}$ in $25 \mathrm{ml} 0.02 \mathrm{M}$-sodium phosphate buffer $\mathrm{pH} 7.0$ containing $0.001 \mathrm{M}$ EDTA.

ruminal $\mathrm{pH}$ in sheep on the roughage diets was between 6.5 and $6 \cdot 7$, and on the roughageconcentrate diets was 6.3 to 6.5 . On the pelleted-barley diet the rumen $\mathrm{pH}$ was always significantly lower, about $\mathbf{5 . 2}$. The low $\mathrm{pH}$ and a rumen flora which is very different from that of animals on the more normal roughage-containing diets (Eadie \& Mann, 1970), coupled with the fact that there is a turn away from ad libitum grain diets in practical feeding of ruminants, suggested that attention should be concentrated on the ureolytic activity in animals on the roughage diets.

Effect of acetohydroxamic acid. Preincubation of rumen fluid from sheep I with $\mathrm{I} \times \mathrm{IO}^{-2} \mathrm{M}$ AHA inhibited ureolytic activity completely, $5 \times 10^{-5}$ M-AHA produced $50 \%$ inhibition of activity, while $5 \times 10^{-6} \mathrm{M}$-AHA had no effect. In a similar experiment, $50 \%$ inhibition of the 
ureolytic activity of a culture of Proteus vulgaris was produced by $2.5 \times 10^{-5} \mathrm{M}-\mathrm{AHA}$. These results suggest the rumen ureolytic activity is from a urease.

Location of ruminal urease activity. The urease activity in sheep I was not associated with the larger solid matter, since the urease activities of the whole and strained rumen fluids were the same (2.25 i.u./ml, Table 3). After low-speed centrifugations (CRF-1 to -3), which would sediment protozoa and some larger bacteria, $95.7 \%$ of the SRF activity was found in the supernatant. After centrifugation of the supernatant from CRF-I, the sediment (bacterial fraction) contained $97.4 \%$ of the activity. After sonication of the resuspended bacterial fraction, $65 \%$ of the activity was in supernatant and the remainder in the sediment.

These experiments, coupled with the fact that urease activity was found in the ciliate-free lambs and in sheep on a barley diet (the diet precludes ciliates from these sheep), suggest that ruminal urease activity is associated with the small bacterial fraction of the rumen flora.

\section{Isolation of ureolytic bacteria}

Direct isolation. Of over $\mathrm{I} 200$ isolates (from a number of samples from sheep I and 3) screened for urease activity, only six were positive. From media 98-5, 10, CM, RO and RORF, 320, I60, 60, 40 and 40 isolates were taken, respectively, all of which were ureasenegative. From 200 isolates on medium 2, strains 21 and 52 were found in the $10^{6}$ and $10^{5}$ dilutions of rumen contents, respectively. Bacterium KI was found at the $10^{4}$ dilution in 40 isolates from medium 2 a. From 200 isolates in medium U, strain 109 was isolated in the $10^{5}$ dilution, and $5 R$ and $6 R$ were found in 100 isolates in medium $G R$ at $10^{5}$ dilution. The total viable counts from the two sheep in media $98-5,2$ and $U$ were between $5 \times 10^{8}$ and $6 \times 10^{8} / \mathrm{ml}$.

The bacteria 2I, 109, 5R and 6R were identified as Staphylococcus using the methods of Baird-Parker (1966), with 5R, 6R and 2I assigned to group II and 109 to group VI. Bacterium 52 was identified as Lactobacillus casei var. casei using the methods of Sharpe, Fryer \& Smith (I966), and KI was identified as Klebsiella aerogenes using the procedure of Cowan \& Steel (1966).

The specific urease activities (see Methods) of cultures of these bacteria determined after growth for $20 \mathrm{~h}$ in medium 2 were: $5 \mathrm{R}, 0.018 ; 6 \mathrm{R}, 0.019 ; 2 \mathrm{I}, 0.027 ; 109,0.022 ; 52,0.015$; $\mathrm{KI}, 0.018$. These values were similar to that $(0.019)$ obtained from cultures of a ureolytic strain of Peptostreptococcus provostii which had been isolated from a steer on a ureamolasses diet by Elias (1971).

Enrichment methods. Since the previous experiments did not appear to have yielded any bacteria which could fully account for the ruminal urease activity, enrichment culture methods were tried.

Rumen fluid from sheep I was fractionated as previously described, and the final sediment (CRB) was examined microscopically. A typical, preponderantly Gram-negative, rumen flora was found. Since a number of peptostreptococcus-like bacteria were present (as in most rumen samples), and since Elias (197I) had isolated ureolytic peptostreptococci from the rumen of cattle on a molasses-urea diet while Huet \& Aladame (1952) had quoted a ureolytic Diplococcus (Peptostreptococcus) magnus, an attempt was made to enrich rumen fluid with a ureolytic peptostreptococcus.

Enrichment medium A was chosen because similar media have been used in the investigation of Megasphaera (Peptostreptococcus) elsdenii, a common rumen bacterium. When this medium was inoculated $(0.5 \%)$ with a sample of rumen fluid from sheep I, a 17 -fold enrichment of urease activity was obtained after anaerobic incubation for $24 \mathrm{~h}$ and the activity was 26 -fold enriched at $48 \mathrm{~h}$. The activity was maintained by daily subculturing using a 
Table 4. Identification of Streptococcus isolate

Test

No. of strains tested

Lancefield group

$\beta$-Haemolysis on blood sugar

Growth at $10^{\circ} \mathrm{C}$

Growth at $45^{\circ} \mathrm{C}$

Growth at pH 9.6

Survival at $60^{\circ} \mathrm{C} / 30 \mathrm{~min}$

$\mathrm{NH}_{\mathbf{n}}$ from arginine

Lactose

Trehalose

Sorbitol

Gelatin liquefaction

Tellurite tolerance

Starch hydrolysis

Glycerol (anaerobic)

Tetrazolium reduction

Growth at $50^{\circ} \mathrm{C}$

Mannitol

Arabinose

Melibiose

Raffinose

Glycerol

Growth in $6.5 \% \mathrm{NaCl}$

\begin{tabular}{|c|c|}
\hline Faecalis & Faecium \\
\hline I & I \\
\hline NT D & NT D \\
\hline NT - & NT - \\
\hline NT+ & NT+ \\
\hline NT+ & NT + \\
\hline NT+ & NT + \\
\hline NT + & NT + \\
\hline $\mathrm{NT}+$ & NT + \\
\hline NT+ & NT + \\
\hline NT & NT \\
\hline+ & - \\
\hline NT - & $\mathrm{NT}-$ \\
\hline+ & - \\
\hline NT - & NT - \\
\hline+ & - \\
\hline+ & - \\
\hline - & + \\
\hline NT + & NT + \\
\hline- & + \\
\hline- & + \\
\hline NT & NT \\
\hline NT & NT \\
\hline NT & NT \\
\hline
\end{tabular}

+ , Positive; - , negative; \pm , very poor growth; NT, not tested, but reaction given in the Tables of Sharpe, Fryer \& Smith (I966) added for reference.

$\mathrm{I} \cdot 5 \%(\mathrm{v} / \mathrm{v})$ inoculum. The first subculture was inoculated from the first $48 \mathrm{~h}$ culture and subsequent transfers were made every $20 \mathrm{~h}$.

On morphological grounds, the population of the enriched cultures appeared to be predominantly Veillonella, with possible Enterobacter, a Gram-negative curved rod, and a very small percentage of a Gram-positive coccus in pairs and short chains. Repeated attempts were made to isolate ureolytic bacteria from these cultures, but in over 800 isolates assayed (not all pure), no ureolytic bacterium was obtained. The Veillonella and Enterobacter were isolated, but were not ureolytic. Several media were used in anaerobic roll-tubes, as in the direct isolation, and on plates incubated under $95 \% \mathrm{H}_{2}-5 \% \mathrm{CO}_{2}$. Media with low nitrogen content were included, as urease activity has been reported to be repressed by ammonia and organic nitrogen compounds (Stewart, 1965; Henderson, 1967).

The Gram-negative curved rod was not isolated from these enrichments, and therefore since, on morphological grounds, it appeared to be a selenomonad, medium B, which had been designed to culture selenomonads, was used. However, a black precipitate complicated assessment of cultures in this medium, so medium $\mathrm{C}$, which gave no precipitate, was developed. Growth of bacteria and urease activities were the same in media B and C; urease activity remained similar to that in medium A. Microscopic observations showed that the Enterobacter and the Gram-negative curved rod were the major components of the culture, and the Gram-positive coccus was again present in small numbers. The Veillonella had been eliminated. Similar results were obtained with enrichment cultures inoculated from medium A or directly with 0.5 to $2 \%(\mathrm{v} / \mathrm{v})$ samples of rumen fluid from sheep I, 3 or 4 or from lamb $C$. 


\section{A ureolytic Streptococcus faecium}

Isolation. In 200 isolates from an enrichment culture in medium C, initially inoculated from a culture in medium A, a Gram-positive coccus was obtained with ureolytic activity but only a small percentage of any culture was ureolytic. This observation was subsequently repeated whenever the stock cultures were diluted.

Identification. The Gram-positive coccus, which grew in pairs and short chains, was a catalase-negative, facultative anaerobe, and was thus classified as a Streptococcus sp. The results of further identification tests (Sharpe et al. 1966; Cowan \& Steel, 1966) (see Table 4) suggested that the bacterium should be classified as a ureolytic strain of $S$. faecium.

Relationship to ruminal urease activity. Although the enzymic activity of a culture containing the bacterium in the numbers in which it occurs in the rumen may be compared with total ruminal activity, conditions in vivo can never be reproduced in vitro. It seemed that a better test of the ability of the streptococcus to grow in the rumen in competition with the major rumen bacteria and to produce urease, could be made by inoculating the streptococcus into the rumen of a gnotobiotic lamb.

Twenty-two days after the inoculation, the streptococcus was re-isolated $\left(2 \times 10^{7}\right.$ c.f.u./g rumen contents). At 68 days the population of the streptococcus was $7 \times 10^{7}$ c.f.u./g. There was no ureolytic activity in rumen contents tested before the introduction of the streptococcus. At 22 days the activity was $0.06 \mathrm{~g}$ urea hydrolysed/100 ml rumen fluid/h and at 68 days the activity was $0.33 \mathrm{~g}$ urea hydrolysed. This latter was comparable with the activity in the normal sheep (Table 2).

Only a small percentage of the streptococci in a ureolytic culture were ureolytic and it was not possible to isolate the streptococcus with ureolytic activity directly from higher dilutions of rumen contents. To determine the number of these streptococci in rumen contents urease activity was ignored and the bacteria were counted as streptococci with the properties shown in Table 4. Medium 2 was used. The urease activity of an inoculum of rumen fluid cultured in this medium was similar to that in the enrichment media. A number of colonies of streptococci, identified as S. faecium, were isolated from the $10^{7}$ dilution cultures of rumen contents from sheep $I$ and 3.

\section{Factors affecting growth and urease activity}

Medium phosphate. In these and all the following tests the culture used to inoculate any media at $\mathrm{I} \%(\mathrm{v} / \mathrm{v})$, was grown for $24 \mathrm{~h}$ in medium $\mathrm{D}$.

Potassium dihydrogen phosphate $\left(0.05 \%\right.$ ) and bicarbonate (from $\mathrm{CO}_{2}$ ) formed the buffering capacity of medium $\mathrm{D}$; the $\mathrm{pH}$ of the medium as inoculated was 6.2 , and after overnight growth it was $6 \cdot 8$. The buffering capacity was increased by using a $I: I(w / w)$ mixture of $\mathrm{Na}_{2} \mathrm{HPO}_{4}$ and $\mathrm{KH}_{2} \mathrm{PO}_{4}$, and adjusting the $\mathrm{pH}$ to 7.4 before autoclaving the medium and dispensing under $\mathrm{CO}_{2}$. Buffer concentrations from $0.1 \%$ were used, and only at concentrations greater than $1 \%(\mathrm{w} / \mathrm{v})$ was there a reduction in growth (from 17.3 units at $0.3 \%$, to 13.8 at $3 \%$ ). Urease activity also fell, though the pecific activity was almost constant.

To obtain the highest growth and to make the phosphate concentration comparable with that in the rumen (Lampila, 1964), $0.3 \%$ sodium-potassium phosphate buffer was used (medium E) except where, as noted, it was changed for specific reasons. However, this medium did not give $\mathrm{Na}^{+}$and $\mathrm{K}^{+}$concentrations as high as those in the rumen.

Acetohydroxamic acid. Preincubation of $\mathrm{I} \mathrm{ml} \mathrm{samples} \mathrm{from} \mathrm{a} 24 \mathrm{~h}$ culture in medium E with $3.5 \times 10^{-5} \mathrm{M}$-acetohydroxamic acid, as described in Methods for rumen fluid, inhibited the streptococcal urease activity by $50 \%$. 
Urea. Urea had no effect on growth in any medium, but without urea there was no urease activity; the maximum urease activity was with $0.3 \%$ urea.

Ammonia. Ammonia was not a nitrogen source for the bacterium nor had it any effect on urease activity when added to medium $\mathbf{E}$ as ammonium chloride at from 0.01 to $0.5 \%$ $(3.2$ to $160 \mathrm{mg} \mathrm{NH} / 100 \mathrm{ml}$ ). The final ammonia concentration in a culture would be that added, plus $110 \mathrm{mg} / 100 \mathrm{ml}$ from hydrolysis of the urea. For comparison, $3 \mathrm{~h}$ after feeding the rumen-fluid ammonia concentration in sheep I was about $14.3 \mathrm{mg} / 100 \mathrm{ml}$.

Carbohydrates. The extent of growth varied with the different carbohydrates. As a low final $\mathrm{pH}$ was produced in some cultures, the buffer system (medium E) was increased to I \% $(w / v)$. The effect on growth and urease activity of $0.2 \%$ of mannitol, glucose, fructose, sucrose, lactose, maltose and cellobiose was tested. These are all sugars generally used in rumen bacteriology, and with the exception of mannitol could be substrates in the rumen. The maximum growth varied, as did the urease activity, the latter being highest with mannitol (0.69 i.u./ml) and lowest with fructose (0.I i.u./ml).

The effects of mannitol and glucose concentration were tested. As similar effects were found when energy or nitrogen sources were increased, only a few indicative results will be given here. Growth increased with increasing mannitol concentration up to $0.2 \%$ and then remained constant ( 17.1 units compared with 9.5 at $0.05 \%)$. However, the specific activity decreased from 0.062 at $0.05 \%$ mannitol to 0.035 at $0.2 \%$ or more of mannitol.

The effect of increasing concentrations of glucose was similar, i.e. an increase in growth with increasing glucose ( 23 units at $0.2 \%$ glucose to 92.2 at $\mathrm{I} \cdot 2 \%$ ) but a decrease in specific urease activity $(0.19$ at $0.2 \%$ glucose to virtually zero at $\mathrm{I} \cdot 2 \%)$. The buffer phosphate was increased to prevent a fall in $\mathbf{p H}$ at high glucose concentrations.

Organic nitrogen compounds. Increasing the organic nitrogen in medium $\mathrm{E}$ increased growth to a certain point (presumably carbohydrate limitation), but the specific urease activity decreased with the increased growth. For example, varying the yeast extract concentration from 0.01 to $1 \%$ resulted in an increase in growth from 2.4 units at $0.01 \%$ to 42.6 at 0.4 to $1 \%$. The specific urease activity decreased from 0.15 at $0.01 \%$ yeast extract to 0.018 at $0.3 \%$. Adding Bactocasitone in varying concentrations to medium $\mathrm{E}$ again increased growth and decreased specific activity (e.g. 0.039 with no Bactocasitone, 0.018 with $0.3 \%$ Bactocasitone). Trypticase, Bactotryptone, Bactotryptose, Bactopeptone or acidhydrolysed casein added to medium $\mathrm{E}$ had the same effect as Bactocasitone.

Volatile fatty acids. Varying the concentration of sodium acetate in medium E from 0.05 to $0.5 \%$ had little effect on growth or urease activity. However, when sodium acetate was omitted there was a slight reduction in urease activity and therefore sodium acetate was retained in medium E. The volatile fatty acid mixture of Caldwell \& Bryant (1966), used in media to provide growth factors for some rumen bacteria, had no effect on growth or urease activity when substituted for acetate in medium $\mathbf{E}$.

Trace elements. It was not possible to investigate the effects of trace elements using medium E without first sequestering with EDTA those cations already present in the medium. The addition of EDTA up to $0.002 \%$ had little effect on growth, but the urease activity (i.u. $/ \mathrm{ml}$ ) was reduced from 0.68 without EDTA to $0.2 \mathrm{I}$ with $0.002 \%$ EDTA. Therefore, in studying the effects of trace elements $0.002 \%\left(5.38 \times 10^{-5} \mathrm{M}\right)$ EDTA was added to medium $\mathrm{E}$.

The addition of $\mathrm{Cu}^{2+}\left(\mathrm{CuSO}_{4} \cdot 5 \mathrm{H}_{2} \mathrm{O}\right)$ or $\mathrm{Mg}^{2+}\left(\mathrm{MgSO}_{4} \cdot 7 \mathrm{H}_{2} \mathrm{O}\right)$ had no significant effect on the specific activity of the culture. The addition of $\mathrm{Fe}^{2+}\left(\mathrm{FeSO}_{4} \cdot 7 \mathrm{H}_{2} \mathrm{O}\right)$ at 3 p.p.m. or $\mathrm{Mn}^{2+}\left(\mathrm{MnSO}_{4} \cdot 4 \mathrm{H}_{2} \mathrm{O}\right)$ at $2 \cdot 46$ p.p.m. or $\mathrm{CO}^{2+}\left(\mathrm{CoCl}_{2} \cdot 6 \mathrm{H}_{2} \mathrm{O}\right)$ at 5 p.p.m. increased the 
specific activity to that of a culture in medium $\mathrm{E}$ without $\mathrm{EDTA}(0 \cdot 039)$. $\mathrm{Zinc}\left(\mathrm{ZnSO}_{4} \cdot 7 \mathrm{H}_{2} \mathrm{O}\right)$ increased the specific activity to a maximum of only 0.028 when at 3.4 p.p.m.

Since the specific activity with the cations and EDTA was never greater than in medium $E$ without EDTA, it was assumed that the yeast extract satisfied the trace-element requirements of the streptococcus.

Oxidation-reduction. Cysteine $\mathrm{HCl} . \mathrm{H}_{2} \mathrm{O}(50 \mathrm{mg} / 100 \mathrm{ml})$ replaced sodium thioglycollate $(75 \mathrm{mg} / 100 \mathrm{ml})$ without affecting growth or urease activity of the streptococcus in anaerobic media. However, although the coccus grew aerobically there was no urease activity in a culture grown aerobically in medium $\mathrm{E}$ without thioglycollate. Urease activity was not regained on continued aerobic subculture or when overnight aerobic growth was used to inoculate an anaerobic subculture, or even after repeated anaerobic subculturing of the first anaerobic culture. There did appear to be some adaptation in growth since growth in the first anaerobic subculture was less ( 8.5 units) than in the aerobic subculture from which it was inoculated (13.3). However, in the second (12.3) and third (14.2) anaerobic subcultures, growth had returned to the level of the aerobic culture.

\section{DISCUSSION}

Ureolytic activity is present in the lamb rumen from an early age. In the very young animal the rumen flora is obtained from the intestine, where lactobacilli, coliforms, streptococci and lactate-utilizing peptostreptococci and veillonella are amongst the predominant organisms. As the animal grows and solid food intake increases, the rumen flora changes to the predominantly Gram-negative, anaerobic flora of the adult rumen. However, the rate and extent of these changes depends on the method of feeding and is not necessarily related to age. The increase in ureolytic activity and its decline, during phase $I$ of feeding of the lambs (Fig. I), is presumably connected with a change in the numbers or types of rumen bacteria, but this change is not connected with diet. Bryant et al. (1958), in a detailed study of calf rumen bacteria, found that the highest numbers of lactate-fermenting bacteria, coliforms and facultative anaerobes were found in samples taken at I and 3 weeks, and then declined. These calves were fed on milk, with access to roughage. The ingestion of solid food, such as grass, stimulates physical development of the rumen, as well as development of an adult flora, and the second increase in activity was obviously connected with the introduction of dried grass - at day 28 in lambs A and B, but delayed until day 45 in lamb C. In lambs A and B the urease activity then remained at about the level associated with an adult sheep on the particular diet. In the adult sheep the urease activity varied with diet (Table 2), which conflicts with the conclusions of Clifford, Bourdette \& Tillman (1968) that urease activity in steers fed on a mixed diet, cottonseed hulls, alfalfa hay or prairie hay did not vary significantly. What is more surprising here is that the activity was lower when the hay or dried grass in diets was partly changed for a grain-containing concentrate, because the addition of more, easily fermented carbohydrate (maize starch) to these diets increased the activity. The addition of starch to the diet might be expected to increase overall rumen microbial activity, and indeed the highest activities (found in the sheep on ad libitum barley diets) might be ascribed to the fact that such animals have a greater concentration of microorganisms, and a higher percentage of viable bacteria, in the rumen than do animals on more conventional and restricted diets (Eadie \& Mann, 1970).

The addition of urea either to the roughage-concentrate or to the barley diet did not change the rumen ureolytic activity. This result differs from that of Caffrey et al. (I967) who found that ureolytic activity was greater when the diet contained urea, and from that of Chalupa 
et al. (1970) who showed that the specific activity of urease was lower in extracts of bacteria from urea-fed sheep. These varying results might be explained by differences in the nitrogento-carbohydrate balance in the diets. The sheep in the present work were feeding on diets usually considered adequate in nitrogen, so addition of further nitrogen as urea, or replacement of protein nitrogen by urea (barley diets) might not be expected to increase overall microbial growth. Since urea is always present in ruminant saliva, sufficient urea would always be available to act as an inducer of urease.

The inhibition of ammonia production from urea in sheep rumen fluid is evidence for the action of a urease, and agrees with the findings of Bainter (1967) who used goat contents, and of Jones (1968) and Brent, Adepoju \& Portela (1971) who used bovine rumen contents or preparations from them. On the basis of experiments with $\left[{ }^{14} \mathrm{C}\right]$ urea, Farlin, Brown \& Garrigus (1968) suggested that there was significant non-hydrolytic metabolism of urea in rumen contents, but further experiments (Brookes et al., 1972) showed that urea was completely metabolized hydrolytically.

The fractionation of rumen contents suggested that the ciliate protozoa were not ureolytic in conformity with the tests of Abou Akkada \& Howard (1962) and Naga \& El-Shazly (I968) on the isolated protozoa Entodinium caudatum and Eudoplodinium medium. The location of the urease in the bacterial fraction confirms the work of Gibbons \& McCarthy (I957) and Jones, MacLeod \& Blackwood (1964a). The release of urease by sonication probably supports the conclusions of Brent et al. (1971) that the urease is intracellular, although the urease could also be bound to the walls.

The results of the initial attempts at isolation of ureolytic bacteria by direct dilution and culture of rumen contents agree with previous work, but they also accord with the properties of the ureolytic $S$. faecium. The surroundings of the ruminant, especially when animals are kept indoors, are conducive to continued inoculation of the rumen by bacteria, whether airborne from other animals, contained in foodstuffs or excretions from other animals, or from the ground. The young ruminant acquires its major rumen flora in this way, but there are always numbers of bacteria which are unsuited for multiplication in the rumen and so remain in low numbers. Also, as the diet of the young ruminant changes, bacteria which were predominant during milk feeding become a minor part of the adult flora. The bacteria isolated in the first experiments would seem to belong to these classes. The staphylococci and klebsiella could enter the rumen from a variety of sources. The lactobacillus could have come initially from the pre-ruminant flora and it might be a more important source of urease in the milk-fed lamb. On the other hand, group D streptococci are regularly found in animals of all ages and appear to be stable components of the rumen population.

The results of the direct-isolation experiments agree with those of most other workers who have attempted isolation using selective or non-selective media. In some cases the examination was directed towards the isolation of facultative anaerobes. Mackay \& Oxford (1954), using selective media, isolated Klebsiella aerogenes and an unidentified, Gramnegative, facultative rod with urease activity, from calves and a starch-fed sheep. Mann, Masson \& Oxford (1954) and Mann \& Oxford (1955) isolated ureolytic micrococci from the calves used by the previous workers, and from sheep.

Appleby (1955) and Blackburn \& Hobson (1962) were looking for proteolytic bacteria. The latter workers isolated representatives of the major genera of anaerobic rumen bacteria along with minor constituents, and the properties of all isolates were tested (see also Abou Akkada \& Blackburn, 1963). However, although both Appleby (1955) and Blackburn \& Hobson (1962) reported only a few facultative anaerobes (predominantly staphylococci or micrococci) as being ureolytic, Muhrer \& Carroll (1964) briefly reported the isolation of 
ureolytic micrococci, but gave no details of the methods used. Amongst the other reported experiments on ureolytic bacteria Gibbons \& Doetsch (1959) isolated a ureolytic bacterium, assigned to the species Lactobacillus bifidus, from normally fed cattle, but the concentration of this bacterium was only $10^{5} / \mathrm{ml}$ rumen contents and it has not been isolated in other studies. Elias (1971) isolated ureolytic Peptostreptococcus spp. from cattle fed on ureamolasses, but the rumen flora of these animals was very different from that of animals fed on more normal diets. Slyter et al. (1968) were apparently the most successful in isolating ureolytic bacteria. They reported presumptively-identified ureolytic isolates of Propionibacterium sp., Bacteroides sp., Ruminococcus sp., Streptococcus bovis and an anaerobic Lactobacillus sp. However, these bacteria came from cattle fed on semi-synthetic, purified diets, and the levels of urease activity in the bacteria were not determined. There have been no further reports on these bacteria.

In the present experiments, although the media could support growth of all known species of rumen bacteria and the examination was more extensive than those of previous workers, only a small number of ureolytic bacteria was isolated. Although these bacteria are obviously present in most rumen contents, consideration of their urease activity, and especially their low numbers, suggested that they could not be responsible for the major proportion of the rumen urease activity, although they may contribute to it.

Attention was then directed towards enrichment cultures. Enrichment methods for isolation of ureolytic rumen bacteria have been tried before (Gibbons \& McCarthy, 1957; Jones, MacLeod \& Blackwood, 1964b) but, although activity was increased, isolation of the responsible bacteria was unsuccessful. Because the ureolytic activity of the $S$. faecium is apparently lost during multiplication of the bacteria and only a small proportion of the bacteria in any culture are ureolytic, it is not surprising that this bacterium has not previously been isolated in searches for ureolytic bacteria. On the other hand, the bacterium was found in higher numbers in the rumen than the other ureolytic bacteria and its specific activity was higher in cultures $(0.039$ under the same conditions as those given in Results for the other bacteria). The inoculation into the gnotobiotic lamb showed that it could compete in vivo with other rumen bacteria. The ureolytic activity was stable and the activity of the lamb rumen contents, where the streptococcus grew in numbers comparable to those in the normal lamb rumens, was comparable with that of the latter animals.

The urease activity of the streptococcus was inhibited by acetohydroxamic acid at concentrations similar to that which inhibited rumen urease. The other properties determined confirmed that the bacterium is fitted for life and urease production in the rumen. The urease is inducible, but urea is always entering the rumen. The urease activity was not inhibited by ammonia, which is always present in rumen contents, and activity was increased by the presence of $\mathrm{Fe}^{2+}, \mathrm{Mn}^{2+}, \mathrm{CO}^{2+}$ and $\mathrm{Zn}^{2+}$, all ions normally present in the rumen. McNaught, Owen \& Smith (1950) showed that iron was necessary for the utilization of non-protein nitrogen in the rumen. The possible slight stimulatory effect of acetate and the lack of inhibitory effects of other volatile fatty acids would allow urease production in the rumen, where lower volatile fatty acids, particularly acetic acid, are always present. The bacterium could also utilize the carbohydrates most likely to be produced by digestion of feedstuffs.

The possession of a major ruminal enzymic activity by a bacterium to which it is of no use is paralleled by Bacteroides amylophilus, one of the most active proteolytic bacteria in the rumen (Blackburn \& Hobson, 1962), which does not utilize the products of proteolysis (Hobson, McDougall \& Summers, 1968). Since the streptococcus cannot utilize urea as a nitrogen source, urea would not be expected to affect rumen ureolytic activity. Nor would 
addition of urea to media enhance growth of the ureolytic bacteria. If urea hydrolysis provided extra $\mathrm{NH}_{3}$-nitrogen for growth of bacteria other than the $S$. faecium, this would explain the finding of Chalupa et al. (1970) that specific urease activity decreased on addition of urea to the diet.

John, Isaacson \& Bryant (1974) recently isolated a ureolytic strain of Selenomonas ruminantium from the rumen of a steer. This bacterium was present in similar numbers to the $S$. faecium in the sheep rumen (about $10^{7} / \mathrm{ml}$ ) although isolation was erratic. They also isolated ureolytic Gram-negative straight rods and facultative Gram-negative rods. The medium used contained urea as sole source of nitrogen, and so the $S$. faecium if present, in the rumen, would not have grown. Although Sel. ruminantium is one of the most common rumen bacteria, ureolytic strains have not previously been reported and were not isolated from the present enrichment cultures. Urease activity in the isolate of John et al. (1974) was inhibited by ammonia and the specific activity was 50 to $55 \mathrm{nmol}$ $\mathrm{NH}_{3} / \mathrm{min} / \mathrm{mg}$ protein. In the same units the specific activity of the $S$. faecium, grown in medium $\mathrm{C}$ with $0.5 \%$ yeast extract, was 70000 . The streptococcus could thus be far more active under rumen conditions than the selenomonad.

The present results, then, suggest that the $S$. faecium contributes the major part of the rumen ureolytic activity in sheep on a roughage diet, and possibly in other animals. The properties of the bacterium could explain why it has not previously been isolated.

Only a few of the bacteria in any culture appeared to be ureolytic. In the experiments with different kinds and amounts of carbohydrates and nitrogen compounds, the specific urease activity decreased with increasing growth. When maximum growth with a particular concentration of any of the substrates tested was plotted against the specific activity, all points fell on an exponential-type curve where specific activity ranged from about 0.063 at a growth of about 10 extinction units to about 0.0005 at a growth of about 110 units. These results suggested no specific effects on urease synthesis, such as amino-nitrogen repression or effects of $\mathrm{C}$ - or N-limitation of growth, but only a diluting out of enzyme activity with increasing bacterial mass. The growth of the streptococcus in the sheep rumen is small ( $10^{7}$ bacteria $/ \mathrm{ml}$ ) and overall growth rate in the rumen is low, so that activity might be retained more in this habitat than in vitro. However, consideration of this loss of activity in vitro, the nonessentiality of urease (ammonia is not a nitrogen source) to the bacterium, and the loss of activity on aerobic growth, suggested that the urease activity might be coded for on a plasmid. Experiments to demonstrate the probable presence of a plasmid are described in the following paper (Cook, 1976).

I thank Dr M. I. Chalmers for rumen samples from sheep 8, 9 and Io, Dr E. R. Ørskov for rumen samples from sheep II and I2, Mrs M. Cowie for technical assistance and Dr P. N. Hobson for helpful discussions.

\section{REFERENCES}

Abou Akkada, A. R. \& Howard, B. H. (1962). The biochemistry of rumen protozoa. V. The nitrogen metabolism of Entodinium. Biochemical Journal 82, 31 3-320.

Abou AkKadA, A. R. \& BlackbuRN, T. H. (1963). Some observations on the nitrogen metabolism of rumen proteolytic bacteria. Journal of General Microbiology 3r, 46I-469.

AppleBY, J. C. (1955). The isolation and classification of proteolytic bacteria from the rumen of the sheep. Journal of General Microbiology 12, 526-533.

BAnNTER, K. (1967). Az acetohidroxamsav hatása a karbamid lebomlására a bendöben Allattenyésztés 16 , $283-288$. 
BAIRD-PARKER, A. C. (1966). Methods for classifying Staphylococci and Micrococci. In Identification Methods for Microbiologists. Part A. Society for Applied Bacteriology; Technical Series, No. 1, pp. 59-64. Edited by B. M. Gibbs \& F. A. Skinner. London: Academic Press.

Blackburn, T. H. \& Hobson, P. N. (1962). Further studies on the isolation of proteolytic bacteria from the sheep rumen. Journal of General Microbiology 29, 69-81.

Brent, B. E., ADepoju, A. \& Portela, F. (197I). In vitro inhibition of rumen urease with acetohydroxamic acid. Journal of Animal Science 32, 794-798.

Brookes, I. M., OWEns, F. N., IsaACS, J., Brown, R. E. \& Garrigus, U. S. (1972). Urea and sodium bicarbonate metabolism by ruminants and by ruminal microorganisms. Journal of Animal Science $\mathbf{3 5}$, 877-882.

BRYANT, M. P. \& BURKeY, L. A. (1953). Culture methods and some characteristics of some of the more numerous groups of bacteria in the bovine rumen. Journal of Dairy Science 36, 205-21 7.

Bryant, M. P. \& Robinson, I. M. (196I). An improved nonselective culture medium for ruminal bacteria and its use in determining diurnal variations in numbers of bacteria in the rumen. Journal of Dairy Science 44, 1446-1456.

Bryant, M. P., Small, N., Bouma, C. \& Robinson, I. (1958). Studies on the composition of the ruminal flora and fauna of young calves. Journal of Dairy Science 41, 1747-1767.

Caffrey, P. J., Hatfield, E. E., Norton, H. W. \& Garrigus, U. S. (1967). Nitrogen metabolism in the ovine. I. Adjustment to a urea-rich diet. Journal of Animal Science 26, 595-600.

CALDWEll, D. R. \& BRYANT, M. P. (I966). Medium without rumen fluid for nonselective enumeration and isolation of rumen bacteria. Applied Microbiology 14, 794-801.

Chalupa, W., Clark, J., Opliger, P. \& Lavker, R. (1970). Ammonia metabolism in rumen bacteria and mucosa from sheep fed soy protein or urea. Journal of Nutrition 100, 161-169.

Clifford, A. J., Bourdette, J. R. \& Tillman, A. D. (1968). Studies on ruminal urease activity. Journal of Animal Science 27, 814-817.

Cook, A. R. (1972). Ureolysis in the ovine rumen. Biochemical Journal 127, P66.

Cook, A. R. (1976). The elimination of urease activity in Streptococcus faecium as evidence for plasmidcoded urease. Journal of General Microbiology 92, 49-58.

CowAN, S. T. \& STEEL, K. J. (1966). In Manual for the identification of medical bacteria. p. 56. Cambridge: Cambridge University Press.

EADIE, J. M. \& MANN, S. O. (1970). Development of the rumen microbial population: high starch diets and instability. In Physiology of digestion and metabolism in the ruminant. Proceedings of the Third International Symposium, Cambridge, 1969, pp. 335-347. Edited by A. T. Phillipson. Newcastle upon Tyne: Oriel Press Ltd.

ELIAS, A. (1971). The rumen bacteria of animals fed on a high-molasses-urea-diet. Ph.D. thesis, University of Aberdeen.

Elsden, S. R., Volcani, B. E., Gilchrist, F. M. C. \& Lewis, D. (1956). Properties of a fatty acid forming organism isolated from the rumen of sheep. Journal of Bacteriology 72, 68I-689.

FarLIN, S. D., BRoWN, R. E. \& GarRIGUS, U. S. (1968). In vivo metabolism of biuret and urea by sheep. Journal of Animal Science 27, 771-775.

Fasman, G. D. \& NiEMANN, C. (I95I). A reinvestigation of the kinetics of the urease-catalysed hydrolysis of urea. I. The activity of urease in the presence of sodium and potassium phosphate. Journal of the American Chemical Society 73, 1646-1650.

Fishbein, W. N., Daly, J. \& STreeter, C. L. (1969). Preparation and some properties of stable and carbon-I4 and tritium-labelled short-chain aliphatic hydroxamic acids. Analytical Biochemistry 28, 13-24.

GibBons, R. J. \& Doetsch, R. N. (1959). Physiological study of an obligately anaerobic ureolytic bacterium. Journal of Bacteriology 77, 41 7-428.

GibBons, R. J. \& MCCARTHY, R. D. (1957). Obligately anaerobic urea-hydrolyzing bacteria in the bovine rumen. In University of Maryland, Agricultural Experiment Station, Miscellaneous Publication No. 29I, pp. $12-16$.

Gorin, G. \& ChIN, C. C. (1966). Urease. VI. A new method of assay and the specific enzymic activity. Analytical Biochemistry 17, 49-59.

HenDERson, A. (1967). The urease activity of Acinetobacter lwoffi and A. anitratus. Journal of General Microbiology 46, 399-406.

Hobson, P. N. (1969). Rumen bacteria. In Methods in Microbiology, vol. 3B, pp. 133-149. Edited by J. R. Norris and D. W. Robbins. London: Academic Press.

Hobson, P. N., McDougall, E. I. \& Summers, R. (1968). The nitrogen sources of Bacteroides amylophilus. Journal of General Microbiology 50 , i.

Hutt, M. \& Aladame, N. (1952). Recherches sur l'uréase des bactéries anaérobies. Annales de l'Institut Pasteur 82, 766-767.

HuNGATE, R. E. (1950). The anaerobic mesophilic cellulolytic bacteria. Bacteriological Reviews. I4, I-49.

JoHN, A., IsAacson, H. R. \& BRYANT, M. P. (1974). Isolation and characteristics of a ureolytic strain of Selenomonas ruminantium. Journal of Dairy Science 57, 1003-1014. 
JONES, G. A. (1968). Influence of acetohydroxamic acid on some activities in vitro of the rumen microbiota. Canadian Journal of Microbiology 14, 409-416.

Jones, G. A., MacLeod, R. A. \& BlackWood, A. C. (1964a). Ureolytic rumen bacteria. I. Characteristics of the microflora from a urea-fed sheep. Canadian Journal of Microbiology 10, 371-378.

Jones, G. A., MAcLeod, R. A. \& BlackWOOD, A. C. (1964b). Ureolytic rumen bacteria. II. Effect of inorganic ions on urease activity. Canadian Journal of Microbiology ro, 379-387.

Kogut, M. \& Podoski, E. P. (1953). Oxidative pathways in a fluorescent Pseudomonas. Biochemical Journal $55,800-8 I$ Ir.

LAMPILA; M. (1964). Volatile fatty acids, pH and microbial activity in the rumen contents of the cow. Annales Agriculturae Fenniae 3, s3, 1-74.

MACKAY, E. S. M. \& OXFORD, A. E. (1954). Some facultatively anaerobic Gram-negative rods from the rumen of the calf and the sheep. Journal of General Microbiology $1 x, 472-476$.

MCNAught, M. L., OWEN, E. C. \& SMITH, J. A. (1950). The utilization of non-protein nitrogen in the bovine rumen. VI. The effect of metals on the activity of the rumen bacteria. Biochemical Journal 46, 36-43.

ManN, S. O., Masson, F. M. \& OxFord, A. E. (1954). Facultative anaerobic bacteria from the sheep's rumen. Journal of General Microbiology 10, $142-149$.

MANN, S. O. \& OXFORD, A. E. (1955). Relationships between viable saccharolytic bacteria in rumen and abomasum of the young calf and kid. Journal of General Microbiology 12, 140-146.

MANN, S. O. \& STEWART, C. S. (1974). Establishment of a limited rumen flora in gnotobiotic lambs fed on a roughage diet. Journal of General Microbiology 84, 379-382.

Muhrer, M. E. \& Carroll, E. J. (1964). Urea utilising microorganisms in the rumen. Journal of Animal Science 23, 885 .

NagA, M. A. \& El-Shazly, K. (1968). The metabolic characterization of the ciliate protozoon Eudiplodinium medium from the rumen of buffalo. Journal of General Microbiology 53, 305-315.

Pearson, R. M. \& Smith, J. A. B. (1943). The utilization of urea in the bovine rumen. II. The conversion of urea to ammonia. Biochemical Journal 37, 148-153.

Rogosa, M., Mrtchell, J. A. \& Wiseman, R. F. (I95I). A selective medium for the isolation and enumeration of oral and faecal lactobacilli. Journal of Bacteriology 62, 132-1 33.

ShARPE, M. E., FRYER, T. F. \& SMITH, D. G. (1966). Identification of the lactic acid bacteria. In Identification Methods for Microbiologists, Part. A. The Society for Applied Bacteriology. Technical Series, No. I, pp. 65-79. Edited by B. M. Gibbs and F. A. Skinner. London: Academic Press.

Slyter, L. L., OltJen, R. R., KeRN, D. L. \& WeAVER, J. M. (I968). Microbial species including ureolytic bacteria from the rumen of cattle fed purified diets. Journal of Nutrition 94, 185-192.

Stewart, D. J. (1965). The urease activity of fluorescent Pseudomonads. Journal of General Microbiology 41, 169-174.

TrWARI, A. D., Bryant, M. P. \& Wolfe, R. S. (1969). Simple method for isolation of Selenomonas ruminantium and some nutritional characteristics of the species. Journal of Dairy Science 52, 2054-2056.

Weatherburn, M. W. (1967). Phenol-hypochlorite reaction for determination of ammonia. Analytical Chemistry 39, $971-974$.

WiLson, M. K. \& BRIGGS, C. A. E. (1955). The normal flora of the bovine rumen. II. Quantitative bacteriological studies. Journal of Applied Bacteriology 18, 294-306. 